\title{
Periphyton changes over 20 years of chemical recovery of Lake Orta, Italy: differential response to perturbation of littoral and pelagic communities
}

\author{
Antonella CATTANEO*, Michèle DE SÈVE ${ }^{1)}$, Giuseppe MORABITO²), Rosario MOSELLO ${ }^{2)}$ \\ and Gabriele TARTARI ${ }^{2}$ \\ GRIL, Département de sciences biologiques, Université de Montréal, C.P. 6128, succ. Centre Ville, Montréal, QC, H3C 3J7, Canada \\ ${ }^{1)}$ M.A. De Sève Consultants, 1232 Ducharme, app.1, Montréal, QC, H2V 1N4, Canada \\ ${ }^{2)}$ C.N.R., Istituto Italiano per lo Studio degli Ecosistemi, L.go Tonolli 50, 28922 Pallanza, Italy \\ *e-mail corresponding author: antonia.cattaneo@umontreal.ca
}

\begin{abstract}
Lake Orta, a large Italian subalpine lake, has a long history of industrial pollution by acid, ammonia, and metals. A whole-lake liming treatment in 1989-1990 led to a gradual increase in $\mathrm{pH}$ (from 4.4 to 7) and a concomitant decline in ammonia (from 2.5 to $0.05 \mathrm{mg} \mathrm{L}^{-1}$ ) and metal concentrations (e.g., copper: from 35 to $3 \mu \mathrm{g} \mathrm{L^{-1 }}$ ). In this study, we examine the response of the littoral zone, in terms of chemistry and periphyton assemblages, to contamination and recovery of Lake Orta. We compare these findings with a long-term data set of chemistry and phytoplankton collected in the pelagic zone. We sampled periphyton at two sites from the liming period (1989) through 2010 when the lake approached chemical equilibrium. Chemical variables collected in the littoral zone near the periphyton samples followed the same temporal trends observed in the pelagic zone. Chlorophytes, the dominant algae in the preliming period, progressively waned after the calcium carbonate addition. Diatom importance gradually increased to reach up to $80 \%$ of the total biovolume in the most recent years. There was a clear shift in the diatom taxonomic composition over the study period. Acidophilous Pinnularia subcapitata var. hilseana and metal-tolerant Achnanthes minutissima were dominant before liming. With the progressive increase in $\mathrm{pH}$ and decline in metal concentrations, there was successively the dominance of Fragilaria nanoides (formerly identified as Synedra tenera) and Cymbella microcephala in the transition period and of circumneutral Navicula cryptocephala, N. radiosa, and Synedra ulna in the most recent period. Pelagic diatoms were more affected than benthic diatoms by the industrial pollution and their recovery after the liming intervention was slower. Whereas present periphyton diatom assemblages are similar to those observed in nearby unpolluted Lake Mergozzo, pelagic assemblages are still in transition from severe disturbance towards characteristics reported before pollution. Our results suggest that the littoral zone may have acted as a refugium during contamination providing an inoculum for pelagic recolonization.
\end{abstract}

Key words: metal contamination, liming, acidification, diatoms, phytoplankton

\section{INTRODUCTION}

Studies of anthropogenic stress in lakes are usually centered on the response of pelagic communities. Monitoring of impact and recovery are mostly based on open water measurements of chemical and biological characteristics. However, there are increasing evidences suggesting that the littoral zone may respond differently from the open water because stress intensity could be different in the two habitats. The littoral zone is directly affected by watershed inputs, which could either intensify or lessen the contaminant concentrations. Furthermore, contaminant transfer may be slowed in thick benthic biofilms because organisms are densely packed with abiotic material and metals may be bonded by polymers exuded by algae and bacteria (Ivorra et al. 2000).

Planktonic diatoms were more affected than benthic taxa in lakes heavily contaminated by metals in Abitibi, Quebec (Cattaneo et al. 2008) and in Finland (Salonen et al. 2006). A shift towards benthic diatoms has also been documented under other stresses. Planktonic diatoms disappeared almost completely in severely acidi- fied Adirondack lakes (Charles 1985). In a lake affected by watershed fires, benthic diatoms increased in periods of perturbation (Philibert et al. 2003). The higher stress tolerance of benthic taxa relative to the planktonic ones could be ascribed to a superior plasticity of littoral organisms, which are adapted to life in a highly variable environment. This plasticity could lead to the replacement of planktonic taxa by usually benthic ones.

Lake Orta, a large Italian subalpine lake, has a long history of industrial pollution resulting in severe acidification and high metal concentrations (Bonacina et al. 1986). A liming intervention in 1989-90 is leading to progressive lake recovery (Calderoni \& Tartari 2001). The objectives of this study were to examine the response of the littoral zone, in terms of chemistry and periphyton assemblages, to contamination and recovery of Lake Orta. We then compare these findings with a long-term data set of chemistry and phytoplankton collected in the pelagic zone. We aim to test whether the response of the littoral zone to these anthropogenic disturbances is different from that observed in the pelagic water. In particular, we examined the possibility that the littoral zone may provide a refugium in contaminated 


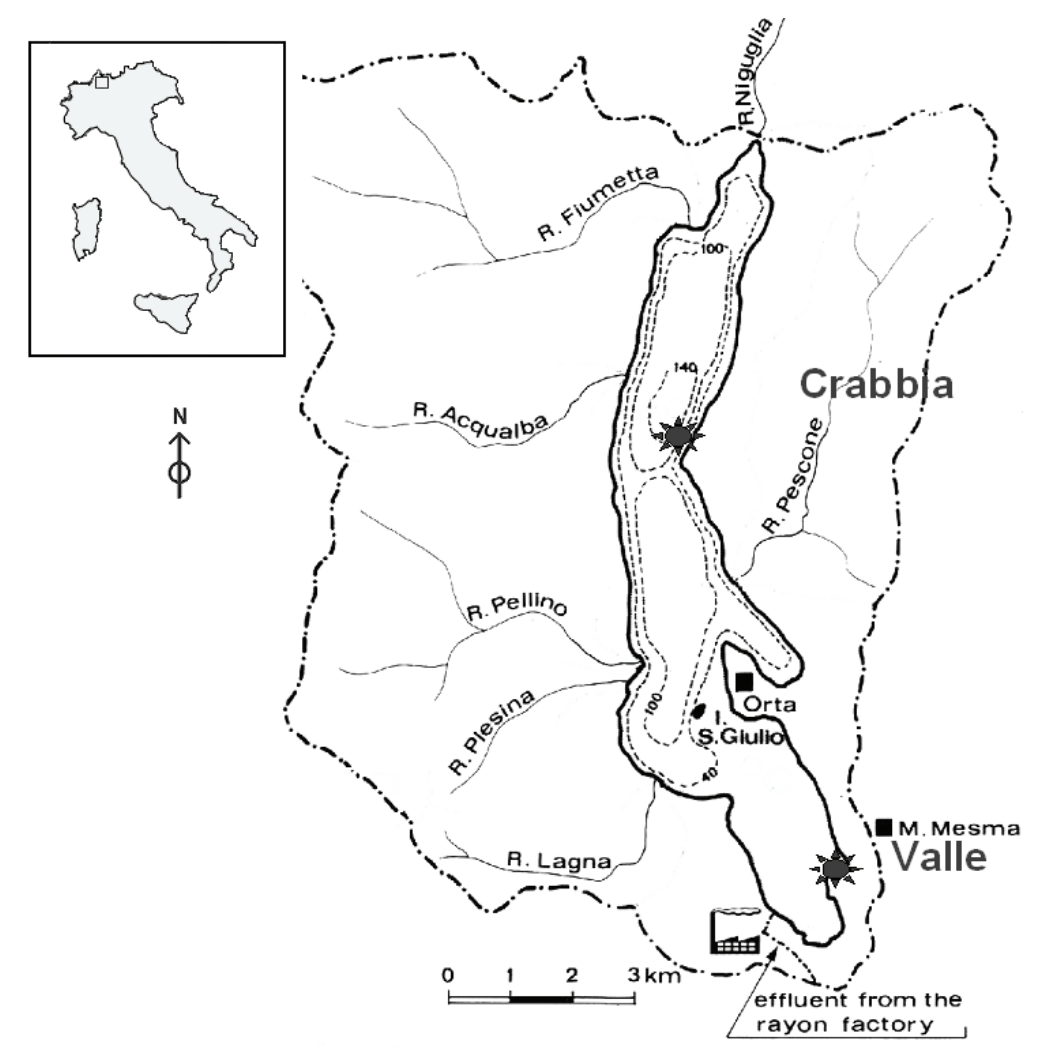

Fig.1. Map of Lake Orta with the two periphyton sampling stations.

lakes in view of the different environmental conditions and the high plasticity of benthic communities.

\section{LAKE ORTA}

Lake Orta (1.3 billion $\mathrm{m}^{3}$, max depth $143 \mathrm{~m}$, surface $18 \mathrm{~km}^{2}$ ) is an important subalpine Italian lake (Fig. 1). The lake basin was created by glacial erosion of a preexisting river valley. Gneiss, micaschists and granites prevail in the catchment basin so that the lake water is naturally poorly buffered. Although mean annual precipitation rates are fairly high $\left(1900 \mathrm{~mm} \mathrm{y}^{-1}\right)$, the theoretical water residence time is quite long $(8.5 \mathrm{y})$ (Mosello et al. 1989). Only a few studies of the lake biota were made before the onset of the pollution in 1926. Nevertheless, they demonstrate that the lake was oligotrophic, rich in high value fish species, and very similar to the other oligotrophic subalpine lakes. In that year, a rayon factory was built on the southern shore of the lake, which directly discharged into the south basin heavy loads of copper and ammonium sulphate (max loads $80 \mathrm{t} \mathrm{Cu} \mathrm{y}^{-1}$ and $3000 \mathrm{t} \mathrm{N} \mathrm{NH}_{4} \mathrm{y}^{-1}$ ) (Bonacina 2001). The early effect was a dramatic disappearance within two years of most biota, mainly due to copper toxicity. In the fifties, only a few phytoplankton species (Oscillatoria limnetica, Choricystis minor), one zooplankton (Cyclops strenuus), and few littoral fish were present; profundal benthos had disappeared.

In 1958, a treatment plant for copper recovery was adopted by the rayon factory; however in the meantime, several plating factories started discharging directly into the lake large quantities of copper $(\mathrm{Cu})$, nichel $(\mathrm{Ni})$, zinc $(\mathrm{Zn})$, and cromium $(\mathrm{Cr})$. Furthermore, since the 1960s, in lake biochemical oxidation of ammonium acidified the lake water, which had naturally poor buffering capacity (total alkalinity $0.30 .4 \mathrm{meq} \mathrm{L}^{-1}$ ) due to watershed geology. The lowest $\mathrm{pH}$ of 3.8 over the whole water column was reached in 1985 (Vollenweider 1963; Bonacina et al. 1986; Calderoni \& Tartari 2001).

Despite actions in the 1980 s to reduce ammonium sulphate discharge, lake water pollution remained high, due to the low $\mathrm{pH}(4.0-4.5)$ produced from the oxidation of the ammonium still present in the water mass, which permitted high concentrations of trace metals (Fig. 2). A liming intervention was proposed by the Istituto Italiano di Idrobiologia (National Research Council) to accelerate lake's recovery from acidification. The liming was done from May 1989 to June 1990 by spreading on the lake surface a suspension of 14,800 $\mathrm{t}$ of finely powdered natural limestone (Mosello et al. 1991; Calderoni et al. 1992; Calderoni \& Tartari 2001).

\section{METHODS}

\subsection{Chemistry}

To monitor the chemical variables in the littoral, subsurface water samples were collected near the stones sampled for periphyton (see below). Pelagic samples were always collected in the zone of maximum depth of the lake. Analyses were performed on samples collected 

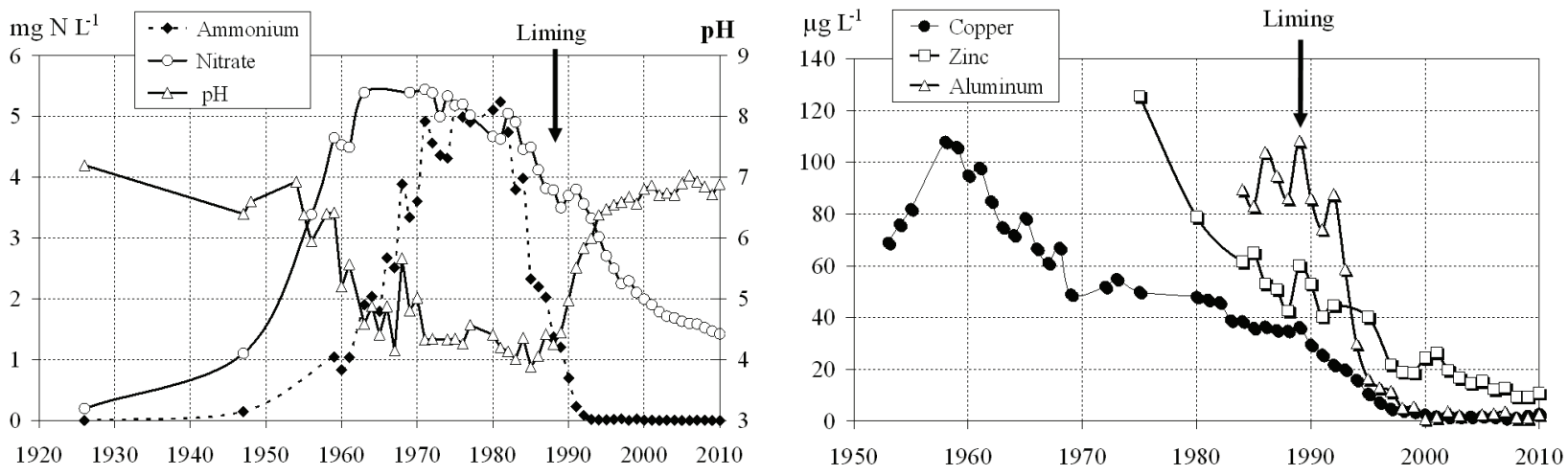

Fig. 2. Trends of concentrations of ammonium, nitrate, and pH (left panel) and of copper, zinc, and aluminum (right panel) measured in Lake Orta at spring circulation (whole lake volume weighted mean values).

near the surface, in the epilimnion (0-25 m), and in the hypolimnion $(25-143 \mathrm{~m})$. Whole lake concentrations were calculated using volume weighted concentrations at the different depths.

All chemical analyses were performed in the laboratory of the Institute of Ecosystem Studies using standard analytical methods for natural water analyses. Details are reported by Tartari \& Mosello (1997). The laboratory adopts strict QA/QC protocols and participates in national and international interlaboratory exercises (Uggerud \& Hjellbrekke 2009a, b; Hovind 2010; Marchetto et al. 2010). Special attention is given to avoid systematic errors due to changes of analytical methods, which may occur in long term studies, such as the present one.

\subsection{Periphyton}

Epilithon was sampled at two stations of Lake Orta (Valle and Crabbia; Fig. 1) in mid-summer (July or August) of 1989, 1992, 1994, 1995, 1998, 2001, 2007, and 2010. We also sampled three times (1994, 1995, and 2010) nearby Lake Mergozzo, which is oligotrophic and with a siliceous watershed as Lake Orta, but escaped pollution because there are no industries in its watershed (Calderoni et al. 1978). Already published data collected in Lake Orta with the same method in 1987 and 1988 before the liming (van Dam \& Mertens 1990; Cattaneo 1992) were integrated, when possible, with the data recorded in the present study during and after liming. At each sampling, five stones lying at depths between 50 and $70 \mathrm{~cm}$ were randomly selected and sampled underwater with a brush-syringe sampler (Loeb 1981). This device scraped periphyton from a constant area of $5.7 \mathrm{~cm}^{2}$ and collected it in a small volume of water. To examine the taxonomic composition, an aliquot of the five pooled replicates was fixed with acetic Lugol's solution. Cell counts and identification were done by the Uthermöhl sedimentation technique with a Zeiss inverted microscope at $1000 \times$ magnification. Subsamples were acid treated and mounted in Hyrax for diatom taxonomic verification. References used for identification and nomenclature were those of Krammer and Lange-Bertalot (1986-1991). Cell volumes were calculated by approximation to solids of known volume.

\subsection{Phytoplankton}

Water samples for phytoplankton analysis were collected monthly from January to December, at the station corresponding to the deepest point of the lake. Only mid-summer data are presented in this paper in order to compare with periphyton that was sampled only in that season. Samples were taken with a Niskin bottle, collecting one sample every $2 \mathrm{~m}$, in order to get an integrated sample in the $0-20 \mathrm{~m}$ water layer. Phytoplankton determinations were carried out on sub-samples preserved in acetic Lugol's solution. Algal cells (including ultraplankton cells of about 3-4 $\mu \mathrm{m}$ diameter) were counted on a Zeiss Axiovert 10 microscope, following Lund et al. (1958), until 400 cells of the most frequent species were counted. Phytoplankton biovolume was estimated from the density data and the original measurements of the cell volume (Hillebrand et al. 1999).

\subsection{Statistical analyses}

Differences in chemistry between littoral and pelagic zone were tested comparing data collected near shore (50-70 cm depth) and in the epilimnion at close dates (median difference $8 \mathrm{~d}$ ) by paired $t$-test (Statistix for Windows, version 9; Analytical Software, Tallahassee, FL). Differences in composition of diatom assemblages between sites and dates were analyzed using Principal Component Analysis (PCA, Canoco 4.5 for Windows). Only diatom taxa representing $\geq 1 \%$ of total biovolume in at least one sample were included in the analysis

\section{RESULTS}

\subsection{Chemistry}

The effects of liming on the main chemical variables were soon evident. By 1991 spring overturn, $\mathrm{pH}$ values had increased from 4.5 to values between 7 and 9 in the 


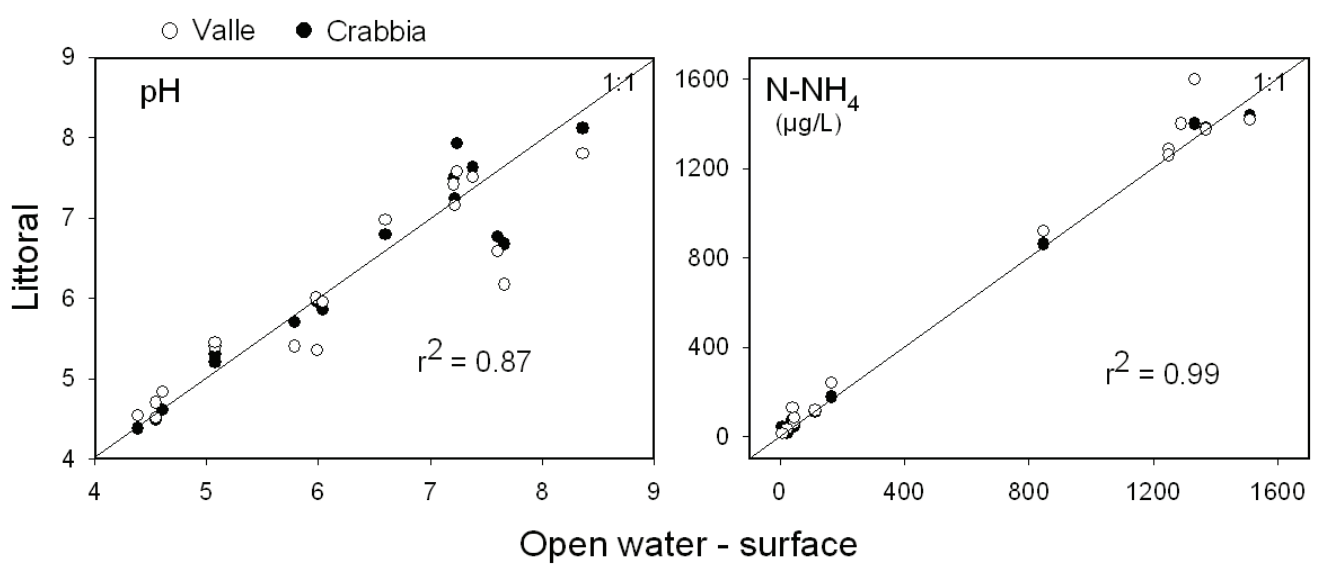

Fig. 3. Comparison between the chemical measurements in the pelagic zone (at the surface) and those at two littoral stations (Crabbia and Valle) in Lake Orta. All samples were collected during the summer (July or August). The observations cover the pre- and postliming period $(1987-2010 ; \mathrm{N}=36)$.

upper $20 \mathrm{~m}$. Ammonium decreased from 90 to $6 \mu \mathrm{eq}$ $\mathrm{L}^{-1}$, very low if compared to values above $300 \mu \mathrm{eq} \mathrm{L}^{-1}$ observed in the seventies (Fig. 2). The mean alkalinity of the lake became positive, thus excluding the danger of a re-acidification of the lake. Trace metal concentrations decreased whereas $\mathrm{pH}$ increased (Fig. 2). After liming, two periods are discernable: 1) a transition period going from 1991 to the mid-90s in which $\mathrm{pH}$ was increasing towards neutrality and metal concentrations were decreasing (e.g., $\mathrm{Cu}$ from 35 to $3 \mu \mathrm{g} \mathrm{L}^{-1}$; $\mathrm{Zn}$ from 80 to $10 \mu \mathrm{g} \mathrm{L}{ }^{-1}$; Al from 100 to $5 \mu \mathrm{g} \mathrm{L}{ }^{-1}$ ) (Mosello et al. 1989; Calderoni \& Tartari 2001); 2) after 1997-1998, there was a chemical stabilisation and the lake reverted to quasi normality. Throughout liming and recovery, Lake Orta stayed oligotrophic. Total phosphorus and reactive phosphorus concentrations remained below 10 and $5 \mu \mathrm{g} \mathrm{P} \mathrm{L}^{-1}$, respectively.

We observed a close agreement between chemistry in the pelagic zone and in littoral stations (Fig. 3). Chemical characteristics (alkalinity, pH, TP, $\mathrm{NO}_{3}$ ) measured in the superficial pelagic water were not significantly different (paired $t$-test; $\mathrm{p}$ from 0.16 to $0.43 ; d f$ from 13 to 35 ) from those measured near the sampled stones. The only exception was $\mathrm{NH}_{4}$, which was on average $10 \%$ higher in the littoral zone than in the open water (paired $t$-test; $p=0.018, d f=27$ ).

\subsection{Periphyton}

Diatoms represented $\sim 20 \%$ of the periphyton total biovolume before liming. Their importance increased after the liming intervention and was consistently over $80 \%$ in the last $10 \mathrm{y}$. Chlorophytes dominated the periphyton assemblages before liming but waned thereafter. Mougeotia and Oedogonium were common during liming but afterwards the most common chlorophytes were Cosmarium spp. and Scenedesmus spp. Cyanobacteria, represented by small filaments of Oscillatoria sp. and Phormidium sp., were somewhat important in the central phase of the recovery (1992-95) (Fig. 4a).

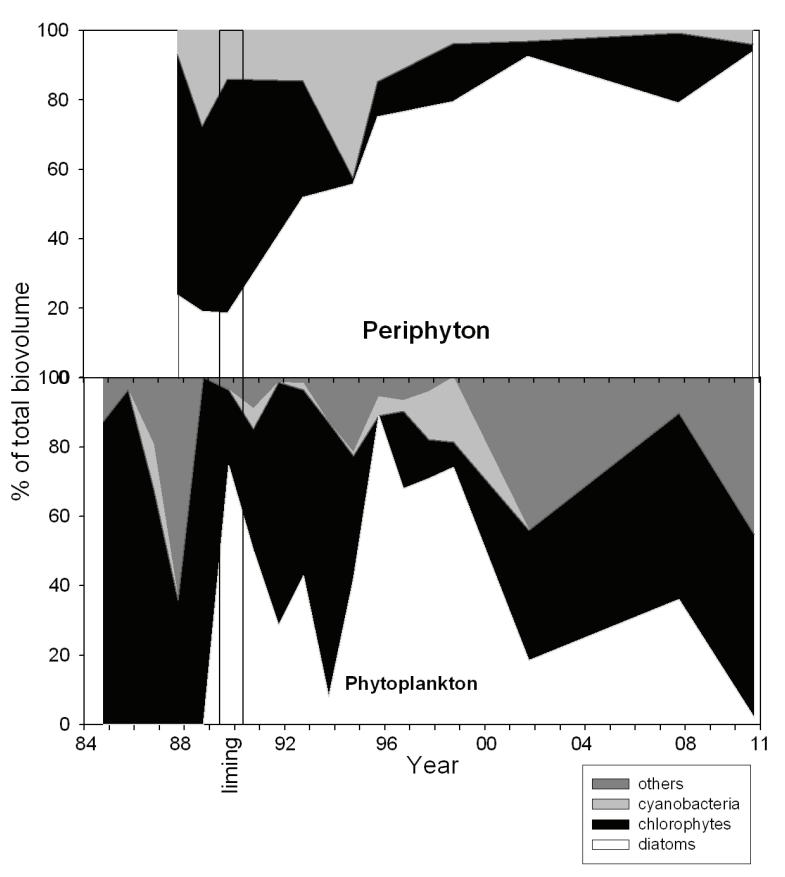

Fig. 4. Temporal trends in the composition (based on biovolume) of periphyton and phytoplankton of Lake Orta through contamination and recovery. Data of 1987 and 1988 are from Cattaneo 1992. Vertical lines indicate the liming period.

We examined the changes in the composition of littoral diatom assemblages over the recovery with a Principal Component Analysis (Fig. 5). The samples were clustered in 3 groups: 1) samples of 1989 collected during the liming; 2) samples from 1992 to 1995; 3) samples from 1998 to 2010 . This last group included the samples collected in 1994, 1995, and 2010 in Lake Mergozzo. This lake was used as a reference because it is geologically similar to Lake Orta but unpolluted

There were clear temporal changes over the recovery in the percent biovolume of the diatoms, which were 
indicated by the PCA as typical of the different phases. Species indicator of acidity (Pinnularia subcapitata var. hilseana) and metal tolerant (Achnanthes minutissima) were important before and during liming but waned afterward. Fragilaria nanoides and Cymbella microcephala were dominant in the transition phase (19921995). Navicula cryptocephala (not represented), $N$. radiosa, and Synedra ulna increased with time (Fig. 6).

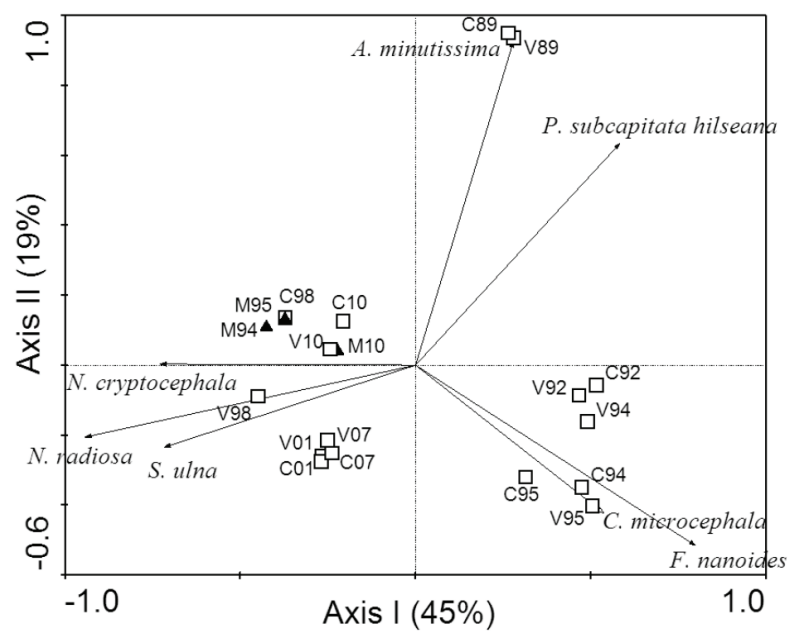

Fig. 5. Plots of sample and species score for Principal Component Analysis of the composition (based on biovolume) of epilithic diatom assemblages collected in summer (July or August) in Lake Orta. Symbols indicate the stations (C: Crabbia - Lake Orta; V: Valle - Lake Orta; M: Lake Mergozzo) and the sampling year (from 1989 to 2010). Arrows represent the diatoms for which $>45 \%$ of the variability was explained by the two first axes of the PCA analysis.

\subsection{Phytoplankton}

Diatoms, which were almost absent in the years immediately preceding the liming, became dominant throughout the intervention (1989-1990). They exhibited other peaks between 1994 and 1999. Lately, their importance, at least in summer, was reduced (Fig. 4b). Chlorophytes (mainly Choricystis minor v. gallica) dominant before liming decreased after the intervention. Other chlorophytes (Westella, Sphaerocystis) became important between 1991 and 1994 and in recent years. Cryptophytes (mainly Cryptomonas) and Dinophytes (mainly Peridinium) were occasionally important. Cyanobacteria (mainly Synechococcus) reached 10\% of biovolume only in 1997 and 1998.

Phytoplankton diatoms assemblages were poor in species. Two taxa, A. minutissima and $F$. nanoides, which were common in the periphyton, were abundant also in the phytoplankton (Fig. 7). Rhizosolenia eriensis and more rarely $R$. longiseta became increasingly common throughout the recovery. Asterionella formosa appeared starting from 1997. Fragilaria crotonensis was recorded in 2010.

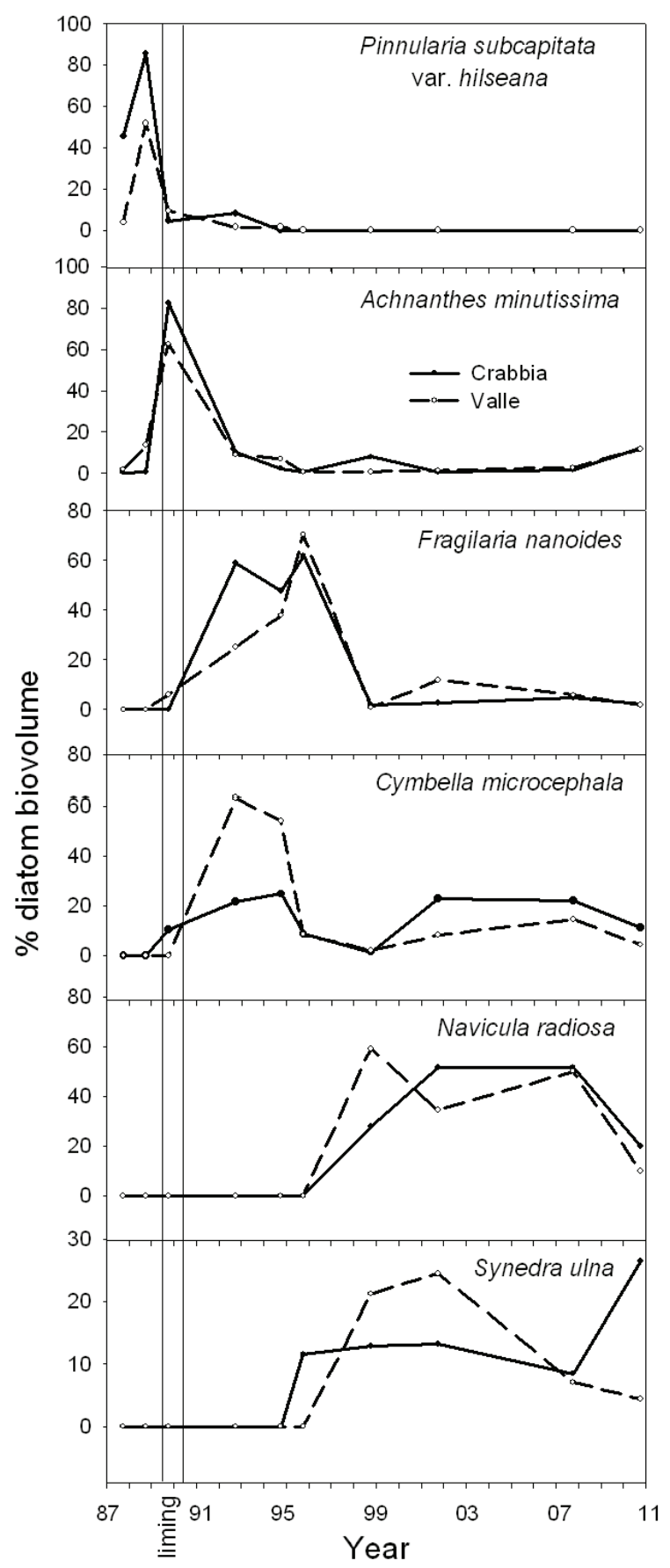

Fig. 6. Temporal trends in the importance (\% of diatom biovolume) of the main diatoms in the periphyton assemblages collected in Lake Orta through contamination and recovery. Data of 1987 and 1988 are calculated from van Dam \& Mertens 1990. Vertical lines indicate the liming period.

\section{DISCUSSION}

\subsection{Chemistry}

Chemistry was apparently similar in littoral and pelagic water during contamination and recovery. Metals were not measured in the littoral zone but we assume they were similar to those recorded in the 
pelagic zone since there was close agreement for all the other chemical variables measured in the two habitats. However, when exploring differences in periphyton and phytoplankton, it is necessary to keep in account that algae in the biofilm mats may experience a different chemical environment than that measured in the overlying water (Lambert et al. 2008).

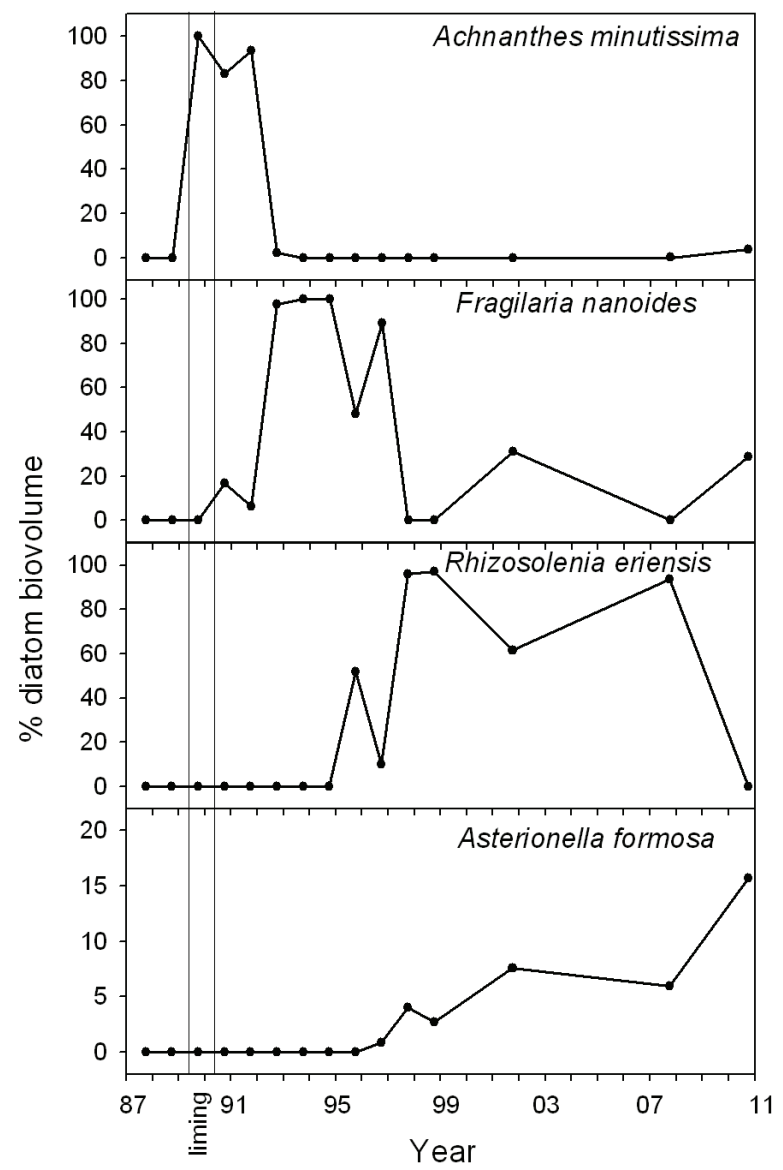

Fig. 7. Temporal trends in the importance (\% of diatom biovolume) of the main planktonic diatoms recorded in Lake Orta through contamination and recovery. Vertical lines indicate the liming period.

Present chemical conditions of Lake Orta, as assessed at spring circulation in 2010, are good with values of total alkalinity $\left(287 \mu \mathrm{eq} \mathrm{L} \mathrm{L}^{-1}\right)$ clearly higher than those recorded immediately after the liming and at the 2000 spring overturn ( 28 and $192 \mu \mathrm{eq} \mathrm{L}{ }^{-1}$, respectively). This increase is related to the alkaline inputs from the tributaries, which are not longer neutralized by in-lake ammonium oxydation. Ammonium concentrations are indeed close to zero, as it is the case in nearby oligotrophic Lake Maggiore and Lake Mergozzo (Vignati et al. 2009). Nitrate concentrations, although still much higher than in Lake Maggiore and Lake Mergozzo due to past contamination, declined from $3702 \mu \mathrm{g} \mathrm{L}^{-1} \mathrm{im}-$ mediately after the liming to 1998 and $1425 \mu \mathrm{g} \mathrm{L}{ }^{-1}$ at spring circulation in 2000 and 2010, respectively (Fig. 2).
Phosphorus concentrations remained low throughout the entire period. Metal concentrations decreased to values comparable to those measured in nearby oligotrophic lakes (Calderoni et al. 1978). In absence of further contaminant inputs from the watershed, Lake Orta should remains in future years in excellent chemical oligotrophic conditions and with alkalinity values as expected in relation to the watershed geology.

\subsection{Periphyton}

At the class level, there was a shift in periphyton composition from chlorophytes to diatoms. Dominance of green algae has been reported for other systems that are either polluted by metals (Foster 1982; Genter et al. 1987) or acidified. In acid lakes (Muller 1980; Turner et al. 1987) masses of filamentous algae, mostly Mougeotia and Zygnema, are common, apparently because these algae can utilize low carbon concentrations and, as hypothesized by Stokes (1984), could be less subject to grazing in acid environments.

In the diatoms assemblages, the taxa dominant before liming ( $P$. subcapitata var. hilsesiana and Eunotia exigua) were typical of acid environments (van Dam \& Mertens 1990). A. minutissima already abundant at the Valle station in 1988 (van Dam \& Mertens 1990) became dominant during and immediately after the liming. This taxon is metal tolerant and often thrives under severe contamination (Takamura 1990; Cattaneo et al. 2004). C. microcephala, which became important during the first part of the recovery, was observed also in limed lakes in Sweden (Anderson et al. 1997). In these same limed lakes, it was important also Fragilaria acus a diatom morphologically similar to $F$. nanoides, which dominated in the first phase of the recovery in Lake Orta. F. nanoides is a newly described species observed in a oligodistrophic Finnish lake (Lange-Bertalot \& Metzeltin 1996), which appears to better describe in the number of striae the diatom identified in previous studies of Lake Orta as Synedra tenera. Starting from the 1998 sampling, diatoms assemblages became close in composition to those observed in the epilithon of Lake Mergozzo, a lake that being geologically similar to Orta but without industrial pollution can be considered a reference. $N$. cryptocephala, $N$. radiosa, and S. ulna became dominant. These taxa are considered circumneutral or alkaliphilous (van Dam \& Mertens 1990) and were abundant in diatom assemblages collected on various littoral substrata in 1915, well before the start of the industrial pollution (Giaj Levra 1925). When examining present epilithic diatoms, it can be concluded that Lake Orta has achieved full recovery from its industrial pollution.

\subsection{Comparison between the response of periphyton and phytoplankton}

Phytoplankton is instead indicating that pelagic assemblages are still in transition from severe disturbance towards characteristics observed in nearby lakes or in L. Orta before pollution. In particular, we will 
focus in the following discussion on diatom assemblages because trends observed for the entire phytoplankton over pollution, liming, and recovery were detailed in previous papers (Morabito et al. 1999; Morabito et al. 2001). Cyclotella comensis and Fragilaria crotonensis are the most important diatoms in recent summer phytoplankton of nearby Lake Maggiore (Morabito et al. 2002). According to deep cores collected in L. Orta, various species of Cyclotella $(C$. comensis, C. stelligera and C. bodanica) and F. crotonensis dominated phytoplankton before the start of industrial pollution in 1926 but completely disappeared afterwards (Ruggiu et al. 1998). Cyclotella has not yet been recorded in L. Orta and F. crotonensis has been observed only in the most recent sample (2010). If the finding of this taxon is encouraging, it is however somewhat troubling that only 6 diatom taxa were recorded in the totality of summer phytoplankton samples collected from liming (1989) to now (2010).

Pelagic diatoms were more affected than benthic diatoms by the industrial pollution and their recovery after the liming intervention is slower. Diatoms were absent in phytoplankton before liming whereas they represented close to $20 \%$ of periphyton biovolume in the same period. Diatom blooms after liming were always composed of one dominant taxon. The first bloom, immediately after liming, was made up of A. minutissima, which is a typical benthic taxon of oligotrophic lakes. Its presence in the phytoplankton of L. Orta was sporadically recorded in samplings in the 50-60s (Vollenweider 1963). According to core studies of Lake Orta (Ruggiu et al. 1998), this taxon became dominant at the beginning of the contamination. Fragilaria nanoides (formerly Synedra tenera) and Rhizosolenia eriensis produced blooms in the mid and late 90s, respectively when $\mathrm{pH}$ was neutral and metal concentrations were already strongly reduced. However, these two taxa are indicator of transition in metal contamination. $F$. nanoides (formerly $S$. tenera) was dominant in Lake Dufault in the Abitibi mining region (Quebec) at the onset of copper contamination (Cattaneo et al. 2004) and in L. Orta cores in strata corresponding to incipient industrial pollution (Ruggiu et al. 1998). In both lakes, this dominance was short lived. F. nanoides was displaced by other more tolerant taxa, among which $A$. minutissima, when other metals and acidification compounded the initial $\mathrm{Cu}$ pollution. $R$. eriensis reached high densities during the recovery of Buttle Lake, a British Columbia lake heavily contaminated with metals (Deniseger et al. 1990).

\subsection{Plankton re-colonization from littoral zone?}

Loss of planktonic diatoms in acidified lakes is often documented (Batterbee 1984; Anderson et al. 1997) and their recolonization of lakes after liming can be slow because they lack resting stages. Our comparison of the diatom trends in the benthic and planktonic assemblages of Lake Orta during contamination, liming and recovery suggests that the littoral zone may have acted as a refugium during contamination. A. minutissima was already common in the benthic assemblages before liming and had a bloom in the phytoplankton immediately after this intervention. It is likely that the inoculum for this proliferation came from the littoral. F. nanoidesis was the other diatom contemporaneously common in the two habitats. In this case, it is difficult to establish which habitat provided the inoculum because $F$. nanoidesis was absent in benthos and plankton before liming and became contemporaneously dominant in both assemblages. This taxon is usually considered planktonic but appears to thrive in periphyton where it represented up to $60-70 \%$ of the total biovolume. F. nanoides must actively grow in the periphyton because these percentages are too high to represent only plankton sedimentation. It is likely that this taxon is favoured by high $\mathrm{Si} / \mathrm{P}$ ratios, as generally observed for Synedra-Fragilaria spp. (Tilman et al. 1982).

The slower recovery of diatom in plankton than in periphyton may have several explanations. Metal contamination in lake water has drastically decreased but it is still present. Benthic diatoms may experience reduced metal contamination because ccontaminant transfer is slowed in benthic biofilms where organisms are mixed with abiotic material and polymers exuded by algae and bacteria may bond metals (Ivorra et al. 2000). Plankton diatom may also be limited by the very low concentrations of $\mathrm{P}$ observed in Lake Orta. This limitation may be less severe for periphyton, which being positioned near the land-water interface may have access to land-derived nutrients before they are diluted in the open water (Lambert et al. 2008). Moreover, close algal-microbial proximity is supposed to make nutrient retention and recycling more efficient in periphyton than in phytoplankton (Wetzel 1996).

As a result of the improved chemical characteristics, other biological communities, beside primary producers, have increased their structural complexity with the reappearance of new taxonomical groups. In the zooplankton, Daphnia, absent in the lake since 1930's, is now present with stable populations. The fish fauna already present (Perca fluviatilis, Leuciscus cephalus, Anguilla anguilla) has markedly increased in density and newly reintroduced species (Salmo trutta fario, Salvelinus alpinus, Cyprinus carpio, Tinca tinca) have been successful (Ponti et al. 2010).

\section{ACKNOWLEDGEMENT}

This work was funded by the Natural Science and Engineering Research Council of Canada (Discovery Grant to AC) and by the Italian CNR (Consiglio Nazionale delle Ricerche). AC is grateful to all members of the Istituto per lo Studio degli Ecosistemi in Pallanza (Italy) for their generous hospitality during her visits. 


\section{REFERENCES}

Anderson, N.J., P. Blomqvist \& I. Renberg. 1997. An experimental and palaeoecological study of algal responses to lake acidification and liming in three central Swedish lakes. Eur. J. Phycol., 32: 35-48.

Battarbee, R.W. 1984. Diatom analysis and the acidification of lakes. Phil. Trans. R. Soc. Lond B, 305: 451-477.

Bonacina, C. 2001. Lake Orta: the undermining of an ecosystem. J. Limnol., 60: 1-7.

Bonacina, C., G. Bonomi \& R. Mosello. 1986. Notes on the present recovery of Lake Orta: an acid, industrially polluted, deep lake in North Italy. Mem. Ist. ital. Idrobiol., 44: 97-115.

Calderoni, A. \& G.A. Tartari. 2001. Evolution of the water chemistry of Lake Orta after liming. J. Limnol., 60: 17-26.

Calderoni, A., R. Mosello \& G. Tartari. 1978. Hydrochemistry and chemical budget of Lago di Mergozzo (Northern Italy). Mem. Ist. ital. Idrobiol., 36: 239-269.

Calderoni, A., R. Mosello \& D. Ruggiu. 1992. Sixty years of limnology on Lago d'Orta: a case history of recovery from heavy pollution. In: P. Guilizzoni, G. Tartari \& G. Giussani (Eds), Limnology in Italy. Mem. Ist. ital. Idrobiol., 50: 201-224.

Cattaneo, A. 1992. The anthropogenically stressed periphyton of Lake Orta, Italy. Hydrobiologia, 234: 111-121,

Cattaneo, A., Y. Couillard \& S. Wunsam. 2008. Sedimentary diatoms along a temporal and spatial gradient of metal contamination. J. Paleolimnol., 40: 97-114.

Cattaneo, A, Y. Couillard, S. Wunsam \& M. Courcelle. 2004. Diatom taxonomic and morphological changes as indicators of metal pollution and recovery in Lac Dufault (Québec, Canada). J. Paleolimnol., 32: 163-175.

Charles, D.F. 1985. Relationships between surface sediment diatom assemblages and lakewater characteristics in Adirondack lakes. Ecology, 66: 994-1011.

Deniseger, J., L.J. Erickson, A. Austin, M. Roch \& M.J.R. Clark. 1990. The effects of decreasing heavy metal concentrations on the biota of Buttle Lake, Vancouver Island, British Columbia. Wat. Res., 24: 403-416.

Foster, P.L. 1982. Species associations and metal contents of algae from river polluted by heavy metals. Freshwat. Biol., 12: 17-40.

Genter, R.B., D.S. Cherry, E.P. Smith \& J. Cairns Jr. 1987. Algal periphyton population and community changes from zinc stress in stream mesocosms. Hydrobiologia, 153: 261-275.

Giaj Levra, P. 1925. Diatomee del Lago d'Orta. Atti Soc. Ligustica Sc. Lett., 5: 66-82.

Hillebrand, H., C.-D. Dürselen, D. Kirschtel, U. Pollingher \& T. Zohary. 1999. Biovolume calculations for pelagic and benthic microalgae. J. Phycol., 35, 403-424.

Hovind, H. 2010. Intercalibration 1024. pH, conductivity, alkalinity, nitrate, chloride, sulphate, calcium, magnesium, sodium, potassium, TOC, $\mathrm{Al}, \mathrm{Fe}, \mathrm{Mn}, \mathrm{Cd}, \mathrm{Pb}, \mathrm{Cu}, \mathrm{Ni}$ and Zn. NIVA Report, ISBN 978-82-577-5764-9, Oslo: 75 pp.

Ivorra, N., S. Bremer, H. Guasch, M.H.S. Kraak \& W. Admiraal. 2000. Differences in the sensitivity of benthic microalgae to $\mathrm{Zn}$ and $\mathrm{Cd}$ regarding biofilm development and exposure history. Environm. Toxicol. Chem., 19: 1332-1339.

Krammer, K. \& H. Lange-Bertalot.1986-1991. Bacillariophyceae. Süsswasserflora von Mitteleuropa. Band 2 (1-4). Gustav Fisher Verlag, Stuttgart. Vols. 1-4. Teil 1 (1986, pp. 876) 2 (1988, pp. 596) 3 (1991, pp. 576) 4 (1991, pp. 437).

Lambert, D., A. Cattaneo \& R. Carignan. 2008. Periphyton as an early indicator of perturbation in recreational lakes. Can. J. Fish. Aquat. Sci., 65: 258-265.

Lange-Bertalot, H. \& D. Metzeltin. Oligotrophie-Indikatoren, 800 Taxa repräsentativ für drei diverse Seen-Typen. Iconogr. Diatom., 2: 1-390.
Loeb, S.L. 1981. An in situ method for measuring the primary productivity and standing crop of the epilithic periphyton community in lenthic systems. Limnol. Oceanogr., 26: 394-399.

Lund, J.W.G., C. Kipling \& E.D. Le Cren. 1958. The inverted microscope method of estimating algal numbers and the statistical basis of estimation by counting. Hydrobiologia, 11: $143-170$.

Marchetto, A., R. Mosello, G. Tartari, K. Derome, N. König, N. Clarke \& A. Kowalska. 2010. Atmospheric deposition and soil solution, Working Ring Test 2010. Laboratory ring test for deposition and soil solution sample analyses for the laboratories participating in the EU/Life+ FutMon Project. Report CNR-ISE, 05-10: 59 pp.

Morabito, G. 1999. Six years (1992-1997) evolution of phytoplankton communities in Lake Orta (N. Italy) after the recovery by liming. Proc. $8^{\text {th }}$ International Conference on the Conservation and management of Lakes. Copenhagen, 17-21 May 1999: 4 pp.

Morabito, G., D. Ruggiu \& P. Panzani. 2001. Trends of phytoplankton characteristics and their communities in pre- and post-liming time in Lake Orta (1984-1988). J. Limnol., 60: 39-48.

Morabito, G., D. Ruggiu \& P. Panzani. 2002. Recent dynamics (1995-1999) of the phytoplankton assemblages in Lago Maggiore as a basic tool for defining association patterns in the Italian deep lakes. J. Limnol., 61: 129-145.

Mosello, R., A. Calderoni \& G.A. Tartari. 1989. pH related variations of trace metal concentrations in L. Orta. Sci. Total Environ., 87/88: 255-268.

Mosello, R., A. Calderoni \& R. de Bernardi. 1991. Mass budget as a tool for predicting the response to liming of the acidified, ammonium polluted L. Orta. Verh. int. Ver. Limnol., 24: 1044-1048.

Muller, P. 1980. Effects of artificial acidification on the growth of periphyton. Can. J. Fish. Aquat. Sci., 37: 355-363.

Philibert, A., Y.T. Priarie, I. Campbell \& L. Laird. 2003. Effects of late Holocene wildfires on diatom assemblages in Christina Lake, Alberta, Canada. Can. J. For. Res., 33: 2405-2415.

Ponti, B., R. Piscia, R. Bettinetti \& M. Manca. 2010. Longterm adaptation of Daphnia to toxic environment in Lake Orta: the effects of short-term exposure to copper and acidification. J. Limnol., 69(2): 217-224.

Ruggiu, D., A. Luglié, A. Cattaneo \& P. Panzani. 1998. Paleoecological evidence for diatom response to metal pollution in Lake Orta (N. Italy). J. Paleolimnol., 20: 333-345.

Salonen, V.-P., N. Tuovinen \& S. Valpola. 2006. History of mine drainage impact on Lake Orijävi algal communities, SW Finland. J. Paleolimnol., 35: 289-303.

Stokes, P. 1984. pH-related changes in attached algal communities of softwater lakes. In: G.R. Hendrey (Ed.), Early biotic responses to advancing lake acidification. Butterworth Publish.: 43-61.

Tartari, G.A. \& R. Mosello. 1997. Metodologie analitiche e controlli di qualità nel laboratorio chimico dell'Istituto Italiano di Idrobiologia del Consiglio Nazionale delle Ricerche. Documenta Ist. ital. Idrobiol., 60: 160 pp.

Takamura, N., S. Hatakeyama \& Y. Sugaya. 1990. Seasonal changes in species composition and production of periphyton in an urban river running through an abandoned copper mining region. Jpn. J. Limnol., 51: 225-235.

Tilman D., S.S. Kilham \& P. Kilhman. 1982. Phytoplankton community ecology: the role of limiting nutrients. Ann. Rev. Ecol. Syst., 13: 349-372.

Turner, M.A., M.B. Jackson, D.L. Findlay, R.W. Graham, E.R. De Bruyn \& E.M. Vandermeer. 1987. Early responses of periphyton to experimental lake acidification. Can. J. Fish. Aquat. Sci., 44 (Suppl. 1): 135-149. 
Uggerud, H.T. \& A.-G. Hjellbrekke. 2009a. The twenty-sixth intercomparison of analytical methods within EMEP. NILU Report EMEP/CCC-Report 6/2009.

Uggerud, H.T. \& A.-G. Hjellbrekke. 2009b. Analytical intercomparison of heavy metals in precipitation, 2008. NILU Report EMEP/CCC-Report 5/2009.

van Dam H. \& A. Mertens. 1990. A comparison of recent epilithic diatom assemblages from the industrially acidified and copper polluted Lake Orta (Northern Italy) with old literature data. Diatom Research, 5: 1-13.

Vignati, D.A.L., M. Camusso \& A. Binelli. 2009. Contaminanti negli organismi indicatori. Metalli in traccia: deter- minazione analitica. In: P. Guilizzoni (Ed.), Indagini su DDT e sostanze pericolose nell'ecosistema del Lago Maggiore. Programma 2008-2012. Rapporto annuale 2008. Commissione Internazionale per la protezione delle acque italo-svizzere: 64-68.

Vollenweider, R.A. 1963. Studi sulla situazione attuale del regime chimico e biologico del Lago d'Orta. Mem. Ist. ital. Idrobiol., 16: 21-125.

Wetzel, R.G. 1996. Benthic algae and nutrient cycling in lenthic freshwater ecosystems. In: R.J. Stevenson, M.L. Bothwell \& R.L. Lowe (Eds), Algal ecology: freshwater benthic ecosystems. Academic Press, San Diego: 641-667.

Received: January 2011

Accepted: April 2011 